UDC: $579.846 .2: 22$

\title{
DOSE-DEPENDENT EFFECT OF ELECTRON ACCEPTOR AND DONOR ON DISSIMILATORY SULFATE REDUCTION BY BACTERIA DESULFOVIBRIO PIGER VIB-7 OF HUMAN INTESTINE
}

Ivan V. Kushkevych

Faculty of Pharmacy, University of Veterinary and Pharmaceutical Sciences Brno Palackeho 1/3, CZ-61242 Brno, Czech Republic e-mail: ivan.kushkevych@gmail.com

Growth of Desulfovibrio piger Vib-7 bacteria of human intestine under the influence of the electron acceptor and donor in different concentrations and the parameters of dissimilatory sulfate reduction have been studied. An increased intensity of the bacterial growth and production of hydrogen sulfide by the $D$. piger Vib-7 bacteria was studied under influence of high concentrations of sulfate and lactate (17.4 and $35.6 \mathrm{mM}$, respectively). The largest quantity of hydrogen sulfide $(6.06 \mathrm{mM})$ under influence of $10.5 \mathrm{mM}$ of $\mathrm{SO}_{4}^{2-}$ was detected on the 72 hour of cultivation; while the bacteria $D$. piger Vib-7 used about $58 \%$ of sulfate ion. The largest quantity of acetate $(21.1 \mathrm{mM})$ is detected on the 72 the hour of growth during cultivating the $D$. piger Vib-7 in the medium containing $53.4 \mathrm{mM}$ of lactate. Based on the obtained experimental data surface models of sulfate reduction parameters by $D$. piger Vib-7 under the influence of electron acceptor and donor different concentrations were constructed. These surface models have provided an opportunity to confirm and establish optimum growing points by the studied bacteria, their sulfate consumption and sulfide production, the lactate consumption and acetate accumulation. The correlation coefficients $(r)$ between parameters of the dissimilatory sulfate reduction by the $D$. piger Vib-7 were defined. Strong negative and positive correlations between these parameters have been observed.

Keywords: sulfate-reducing bacteria, Desulfovibrio piger, sulfates, hydrogen sulfide, inflammatory bowel diseases, ulcerative colitis.

\section{INTRODUCTION}

Large intestine is an open system which receives the remains of food from the small intestine together with microbial biomass. It is a system of continuous cultivation of microorganisms [2, 10]. Large intestine of adult human contains more than $200 \mathrm{~g}$ of digestive material. The average daily output of faeces is approximately $120 \mathrm{~g}[6,11]$.

The intestinal biomass contains up to $55 \%$ microorganisms of the total microbial content of faeces people $[6,7,13]$. In the large intestine microbial mass is $10^{11}-10^{12} \mathrm{cell} / \mathrm{g}$ faeces, dominant are genera Bifidobacterium, Bacteroides, Lactobacillus, Escherichia, 
Eubacterium, Enterococcus, Atopobium, Faecalibacterium and Clostridium [2, 11]. Approximately 40 bacterial species are $99 \%$ of the colon microflora [6].

Intestinal microflora has an important role in the physiology and metabolism of the human [5]. Intestinal microorganisms performs directly involved in the digestion processes, metabolizing short-chain fatty acids [2]. They affects on the human physiological functions and health [5, 6, 7, 11, 14].

Sulfate-reducing bacteria (SRB) belong to the microbiocenosis of the human and animals $[2,6,10,11]$. The dominant of SRB in the human intestine are species of the Desulfovibrio genus, they constitute $67-91 \%$ of total number of SRB. It is thought that SRB combined with other infections can cause a variety of diseases including cholecystitis, brain abscesses and abdominal cavity, ulcerative enterocolitis, etc. [5, 11]. The species of the Desulfovibrio genus are often isolated among all SRB during both monoand polymicrobial infections of the gastrointestinal tract. These bacteria are the most pathogenic role of all SRB species [2, 6, 14, 15].

The SRB can metabolize dietary supplements containing oxidized sulfur compounds [2]. Supplements with sulfate in ruminants causes the increase of hydrogen sulfide concentration in the rumen through the presence of SRB. The hydrogen sulfide toxicity manifested clinically, causing weight loss, fever, bloody diarrhea and intestinal inflammation. A large number of sulfur oxides are present in the food as they are added as a preservative to extend shelf life. These preservatives are sulfur dioxide (E220), sulfites (E221-227) and less so carrageenan (E407) all of which are consumed by $98.6 \%$ of the population. The analysis of food and drinks on a sulfate level showed that people who live in more developed western countries, consume over $16.6 \mathrm{mmol}$ sulfate/ day. Consumption of sulfate is a regulatory factor in the reduction of sulfate in the gut [2, $11,13,15]$. It can have an important role in the development of ulcerative colitis $[5,14]$.

To clarify the role of SRB in causing various human diseases is necessary to study the processes of dissimilatory sulfate reduction by the strains of the human intestine, comparing their biochemical, physiological, genetic, morphological properties. It is important to also study the influence of the different concentrations of the electron acceptor and donor on the dissimilatory sulfate reduction processes by SRB, their trophic relationships, and necessary also consider account their diversity in the human intestine. It is of importance to obtain new strains of Desulfovibrio from different people then study their growth and the process of dissimilatory sulfate reduction. The hydrogen sulfide and acetate production by the bacterial strains should also be studied in order to clarify the etiological role of these bacteria in the development of various diseases.

Sulfate-reducing bacteria oxidises organic compounds or hydrogen, they can use a variety of electron acceptors mostly low redox potential $[2,10]$. These acceptors may be sulfate, thiosulfate, sulfite, elemental sulfur [2]. SRB use organic compounds as an electron donor. The most common of the electron donor for SRB in the human intestine is lactate. It was therefore interesting to study the effect of different concentrations of electron acceptor and donor on the bacterial growth $D$. piger and process of dissimilatory reduction of sulfate.

The aim of this research was to study the dissimilatory sulfate reduction by the Desulfovibrio piger Vib-7 of the human large intestine under influence of different concentrations of sulfate and lactate, and carry out correlation analyses of these parameters influence on process.

ISSN 1996-4536 (print) • ISSN 2311-0783 (on-line) • Біологічні Студії / Studia Biologica • 2014 • Том 8/№1 • C. $103-116$ 


\section{MATERIAL AND METHODS}

The objects of the study were sulfate-reducing bacteria of the Desulfovibrio piger strain Vib-7 obtained from the human large intestine [12]. The strain is kept in the collection of microorganisms at the Biotechnology Laboratory of the Pharmacy Faculty at the University of Veterinary and Pharmaceutical Sciences Brno (Czech Republic).

The bacteria were grown in nutrition modified Kravtsov-Sorokin's liquid medium of such composition (g/l): $\mathrm{Na}_{2} \mathrm{SO}_{4}-0.5 ; \mathrm{KH}_{2} \mathrm{PO}_{4}-0.3 ; \mathrm{K}_{2} \mathrm{HPO}_{4}-0.5 ;\left(\mathrm{NH}_{4}\right)_{2} \mathrm{SO}_{4}-0.2$; $\mathrm{NH}_{4} \mathrm{Cl}-1.0 ; \mathrm{CaCl}_{2} \times 6 \mathrm{H}_{2} \mathrm{O}-0.06 ; \mathrm{MgSO}_{4} \times 7 \mathrm{H}_{2} \mathrm{O}-0.1 ; \mathrm{C}_{3} \mathrm{H}_{5} \mathrm{O}_{3} \mathrm{Na}-2.0$; yeast extract 1.0; $\mathrm{FeSO}_{4} \times 7 \mathrm{H}_{2} \mathrm{O}-0.004$; sodium citrate $\times 2 \mathrm{H}_{2} \mathrm{O}-0.3$. Before bacteria seeding in the medium, $0.05 \mathrm{ml} / /$ of sterile solution of $\mathrm{Na}_{2} \mathrm{~S} \times 9 \mathrm{H}_{2} \mathrm{O}(1 \%)$ was added. To provide $\mathrm{pH} 7.2$ of medium sterile $10 \mathrm{~N}$ solution of $\mathrm{NaOH}(0.9 \mathrm{ml} / \mathrm{l})$ was used. The medium was heated in boiling water for $30 \mathrm{~min}$ in order to obtain an oxygen-free medium, and cooled to $+30^{\circ} \mathrm{C}$ temperature. The bacteria were grown for 72 hours at $+37^{\circ} \mathrm{C}$ under anaerobic conditions. The tubes were brim-filled with medium and closed to provide anaerobic conditions.

To determine the effect of different concentrations of electron acceptor in the culture medium additionally was added various amounts of $\mathrm{Na}_{2} \mathrm{SO}_{4}$, final media concentrations of the $\mathrm{SO}_{4}^{2-}$ were $0,87 \mathrm{mM}, 1.75 \mathrm{mM}, 3.5 \mathrm{mM}, 7 \mathrm{mM}, 10.5 \mathrm{mM}$ or $17.5 \mathrm{mM}$. In addition, to study the effect of different concentrations of electron donor in the medium additionally was added various amounts $\mathrm{C}_{3} \mathrm{H}_{5} \mathrm{O}_{3} \mathrm{Na}$, final media concentrations of the lactate were $4.45 \mathrm{mM}, 8.9 \mathrm{mM}, 17.8 \mathrm{mM}, 35.6 \mathrm{mM}, 53.4 \mathrm{mM}$ or $89 \mathrm{mM} \mathrm{C}_{3} \mathrm{H}_{5} \mathrm{O}_{3}^{-}$. Control were medium which contained $3.5 \mathrm{mM} \mathrm{SO}_{4}^{2-}$ and $17.8 \mathrm{mM} \mathrm{C}_{3} \mathrm{H}_{5} \mathrm{O}_{3}^{-}$.

Accumulation biomass of sulphate-reducing bacteria in liquid medium (without Mohr's salt) was determined by turbidity of dilute suspension of cells by photometric method [16].

The sulfate ions concentration in the medium was determined by turbidymetric method after it had been precipitated by barium chloride. To stabilize the suspension, glycerol was used [9].

Hydrogen sulfide in the culture medium was photometrically determined using spectrophotometer $(\lambda=665 \mathrm{~nm}$, cuvette with optical path $30 \mathrm{~mm})$. The reaction mixture had the following composition: zinc citrate $(27.3 \mathrm{mM})-10 \mathrm{ml}$; distilled water $-1.98 \mathrm{ml}$; $n$-aminodimethylaniline solution $(5.5 \mathrm{mM})-4 \mathrm{ml}$, and $20 \mu \mathrm{l}$ of test solution. After $5 \mathrm{~min}$, $1 \mathrm{ml}$ of ferric chloride $(0.125 \mathrm{M})$ was added and methylene blue formation was observed. The concentration of hydrogen sulfide by calibration curve was established.

Determination of lactate concentration was carried out through a dehydrogenation reaction of lactate by lactate dehydrogenase in the presence of $\mathrm{NAD}^{+}$, with formation of pyruvate and $\mathrm{NADH}$. For determination of lactate content the following reagents were used: hydrazine-glycine buffer $\mathrm{pH} 9.0$ (glycine $-0.1 \mathrm{M}$ solution containing $0.1 \mathrm{M}$ hydrazine); $\mathrm{NAD}^{+}-0.03 \mathrm{M}$ solution, $\mathrm{pH} 6.0$; lactate dehydrogenase solution (protein content was about $2 \mathrm{mg} / \mathrm{ml}$ ). The samples of glycine and hydrazine were dissolved in a small amount of distilled water, a pH of 9.0 was maintained by a $2 \mathrm{~N} \mathrm{NaOH}$ solution, then the mixture was diluted by distilled water to $100 \mathrm{ml}$. Solutions of $\mathrm{NAD}^{+}$and lactate dehydrogenase were kept on ice. The content of the tubes was thoroughly mixed and placed inside a thermostat at $+25^{\circ} \mathrm{C}$ for $60 \mathrm{~min}$. After incubation, samples were cooled and then the optical density of the samples was measured at $340 \mathrm{~nm}$. The quantity of the lactic acid was subsequently calculated [17].

Accumulation of acetate ions by the bacterial cells during their growth in the medium was determined by titration [3].

ISSN 1996-4536 (print) • ISSN 2311-0783 (on-line) • Біологічні Студії / Studia Biologica • 2014 • Том 8/№1 • C. 103-116 
Using the experimental data, the basic statistical parameters $(\mathrm{M}$ - mean, $\mathrm{m}$ - standard error, $M \pm m$ ) have been calculated. For the estimation of the reliability between the statistical characteristics, Student's $t$-test was used. The difference was reliable when $\mathrm{P} \geq 0.95$ [1]. Statistical processing of the results was performed using packet Excel and Origin computer programs [8].

The correlation analysis of the parameters was carried using packet Excel program. The main result of a correlation is called Pearson's correlation coefficient (or " $r$ "). It is best represents the contemporary use of the simple correlation that assesses the linear relationship between two variables. The coefficient indicates the strength of the relationship, with values ranging from 0 to 1 in absolute value. The larger the magnitude of the coefficient, the stronger the relationship between the variables. The sign of the coefficient indicates the direction of the relationship as null, positive, or negative. A null relationship between variables $X$ and $Y$ suggests that an increase in variable $X$ is accompanied with both an increase and a decrease in variable $Y$ and vice versa [4].

\section{RESULTS AND DISCUSSION}

The studied sulfate-reducing bacteria the Desulfovibrio piger Vib-7 actively reduced of sulfate and produced of hydrogen sulfide (up to $3.16 \mathrm{mM}$ ) as well as they assimilated of lactate and accumulated of acetate (up to $15.63 \mathrm{mM}$ ) in the control ( $3.5 \mathrm{mM}$ of sulfate and $17.3 \mathrm{mM}$ of lactate) medium (Fig. 1, 2).

Increasing the concentration of sulfate ion as electron acceptor in two $(7.0 \mathrm{mM})$, three $(10.5 \mathrm{mM})$ or five $(17.5 \mathrm{mM})$ times in the culture medium leads to actively growth and producing of hydrogen sulfide by the studied D. piger Vib-7 (Fig. 1).

The stimulation of sulfate reduction is not occurred proportional to the increase of sulfate concentration in the medium. The largest quantity of hydrogen sulfide $(6.06 \mathrm{mM})$ under influence of $10.5 \mathrm{mM}$ of $\mathrm{SO}_{4}^{2-}$ was detected on the 72 hour of cultivation; while the bacteria $D$. piger Vib-7 used about $58 \%$ of sulfate ion. Perhaps, the rest $(42 \%)$ of the electron acceptor was in excess and the bacteria could not assimilate such number of sulfate. Under these conditions the D. piger Vib-7 acumulated up to $5.64 \mathrm{~g} / \mathrm{l}$ of biomass. The increasing of the sulfate ion concentration up to $17.5 \mathrm{mM}$ (in five times) in the medium is not caused biomass increasing and stimulation of hydrogen sulfide production compared to $10.5 \mathrm{mM}$ of sulfate concentration. Perhaps, the dissimilatory sulfate reduction process can limit other factors such as the presence of electron donor in the medium. Moreover, the decrease in the concentration of sulfate up to $1.75 \mathrm{mM}$ and $0.87 \mathrm{mM}$ caused a significant biomass decrease (up to 0.88 and $1.95 \mathrm{~g} / \mathrm{l}$, respectively) and process of sulfate reduction by the $D$. piger Vib-7. Possibly, the low concentrations of electron acceptor were not insufficient for the sulfate-reducing bacteria of the human intestine.

The increase of lactate concentration in two $(35.6 \mathrm{mM})$, three $(53.4 \mathrm{mM})$ or five $(89 \mathrm{mM})$ times stimulated acetate production in the medium by the studied $D$. piger Vib-7 (Fig. 2). The increase of lactate concentration did not lead to a proportional increase of sulfate reduction parameters as was in the case with the increasing of sulfate concentration in the medium. The largest quantity of acetate $(21.10 \mathrm{mM})$ was detected on the 72 hour of cultivation during cultivating the $D$. piger Vib-7 in the medium which contained $53.4 \mathrm{mM}$ of lactate. The bacteria used about $41 \%$ of lactate from the medium under these conditions. Perhaps an excess of lactate in the medium has not been used by the studied bacteria.

ISSN 1996-4536 (print) • ISSN 2311-0783 (on-line) • Біологічні Студії / Studia Biologica • 2014 • Том 8/№1 • C. $103-116$ 

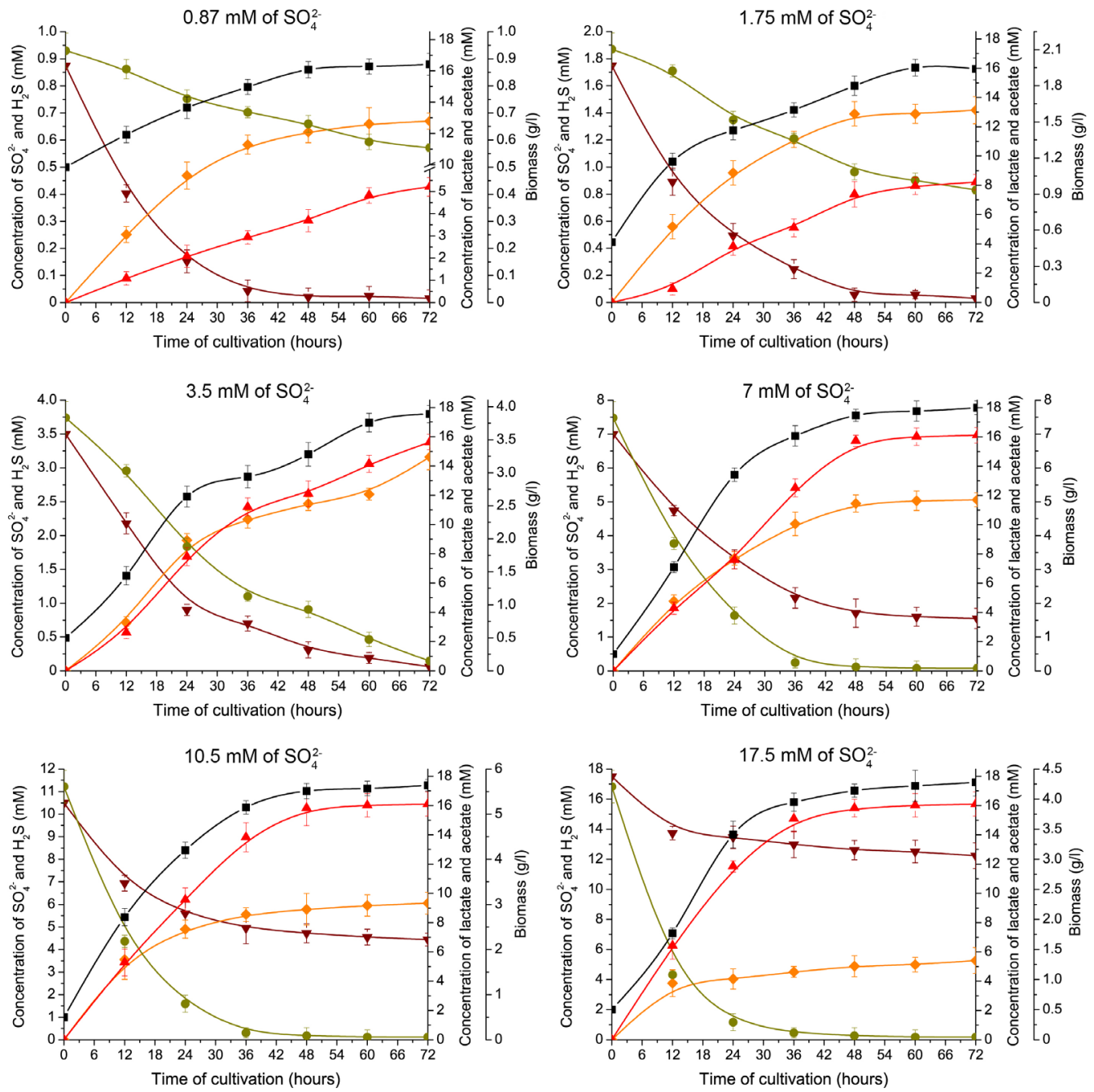

Fig. 1. Influence of different concentrations of electron acceptor on growth and sulfate reduction by Desulfovibrio piger Vib-7 bacteria: - - - biomass, $-\boldsymbol{\nabla}$ - sulfate, $-\downarrow$ - sulfide, $-\bullet$ - lactate, $-\mathbf{\Delta}$ - acetate

Рис. 1. Вплив різних концентрацій акцептора електронів на ріст і відновлення сульфату бактеріями

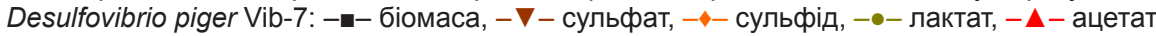

The highest biomass $(7.76 \mathrm{~g} / \mathrm{l})$ was detected when bacterial culture $D$. piger Vib-7 grow in the medium which contained $35.6 \mathrm{mM}$ of lactate. Increasing the concentrations of lactate up to 53.4 and $89 \mathrm{mM}$ in the culture medium did not contribute to increasing level of hydrogen sulfide and growth of the studied sulfate-reducing bacteria.

The decrease in the concentrations of lactate up to 8.9 and $4.45 \mathrm{mM}$ caused the biomass decrease and sulfate reduction parameters as was in the case with the decreasing of sulfate concentration in the medium.

Thus, increasing concentrations of the electron acceptor (sulfate) up to $10.5 \mathrm{mM}$ and electron donor (lactate) up to $53.4 \mathrm{mM}$ in the culture medium contributed to the activation process of the dissimilatory sulfate reduction by the studied $D$. piger Vib-7.

ISSN 1996-4536 (print) • ISSN 2311-0783 (on-line) • Біологічні Студії / Studia Biologica • 2014 • Том 8/№1 • C. $103-116$ 

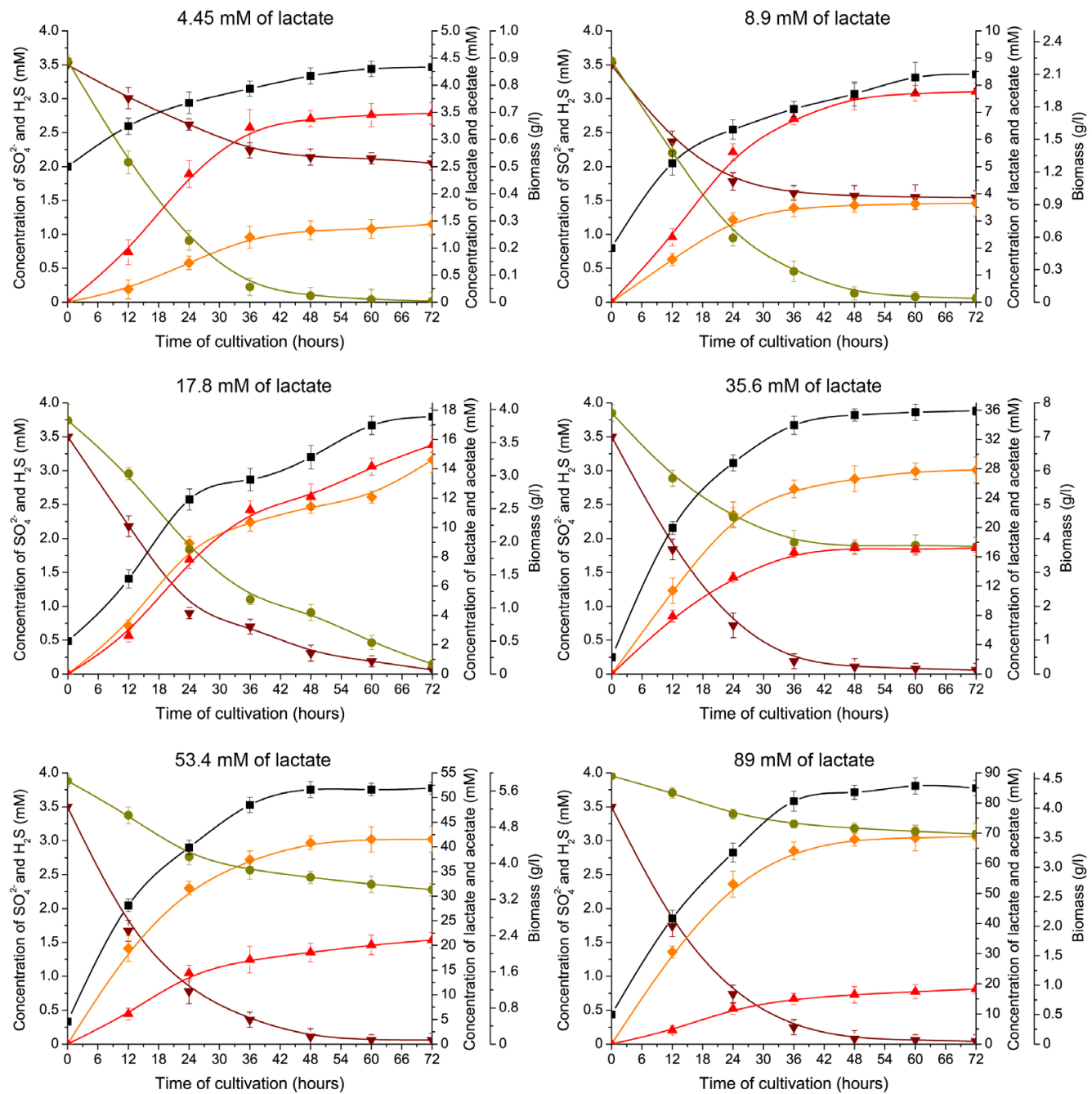

Fig. 2. Influence of different concentrations of electron donor on growth and sulfate reduction by Desulfovibrio piger Vib-7 bacteria: - $-\boldsymbol{-}$ - biomass, $-\boldsymbol{\nabla}$ - sulfate, $-\downarrow-$ sulfide,,$\bullet-$ lactate, $-\mathbf{\Delta}$ - acetate

Рис. 2. Вплив різних концентрацій донора електронів на ріст і відновлення сульфату бактеріями Desul-

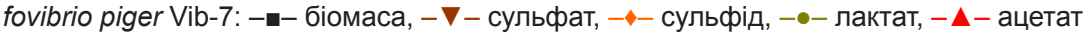

Based on experimental data ten matrices (five matrices $A$ and five matrices $B$ ) have been calculated. The matrix $A$ represented the influence of electron acceptor studied concentrations and the matrix $B$ - the influence of electron donor different concentrations ( $A_{1}$ and $B_{1}$ - matrices for biomass; $A_{2}$ and $B_{2}$ - for sulfate consumption; $A_{3}$ and $B_{3}-$ for production of sulfide; $A_{4}$ and $B_{4}$ - for lactate consumption; $A_{5}$ and $B_{5}$ - for production of acetate). The matrices $B_{1}, B_{2}, B_{3}, B_{4}, B_{5}$ were transformed $\left(B_{1} \rightarrow B_{1}{ }^{\top} ; B_{2} \rightarrow B_{2}^{\top} ; B_{3} \rightarrow B_{3}{ }^{\top}\right.$; $B_{4} \rightarrow B_{4}^{\top} ; B_{5} \rightarrow B_{5}^{\top}$ ). After then the matrices $A$ and transformed matrices $B$ were added $\left(A_{1}+B_{1}^{\top} ; A_{2}+B_{2}{ }^{\top} ; A_{3}+B_{3}^{\top} ; A_{4}+B_{4}^{\top} ; A_{5}+B_{5}^{\top}\right)$. Five main matrices for sulfate reduction parameters were obtained (Table 1). 
Table 1. Matrices of parameters of sulfate reduction by Desulfovibrio piger Vib-7 bacteria under the influence of electron acceptor and donor used in different concentrations

Таблиця 1. Матриці параметрів сульфатредукції, здійснюваної бактеріями Desulfovibrio piger Vib-7 за впливу різних концентрацій акцептора і донора електронів

\begin{tabular}{|c|c|c|c|c|c|c|}
\hline \multicolumn{7}{|c|}{ Matrix of the biomass } \\
\hline 0.5 & 0.57 & 0.62 & 0.64 & 0.67 & 0.68 & 0.43 \\
\hline 0.56 & 1.22 & 1.51 & 2.42 & 2.32 & 1.92 & 1.05 \\
\hline 0.61 & 1.43 & 2.64 & 4.37 & 3.74 & 3.58 & 1.94 \\
\hline 0.65 & 2.95 & 4.58 & 7.14 & 6.39 & 5.83 & 3.88 \\
\hline 0.68 & 2.43 & 3.81 & 6.42 & 5.57 & 4.88 & 2.83 \\
\hline 0.69 & 2.04 & 3.50 & 5.90 & 4.92 & 4.30 & 2.17 \\
\hline 0.44 & 0.97 & 1.94 & 3.89 & 2.82 & 2.14 & 0 \\
\hline \multicolumn{7}{|c|}{ Matrix of sulfate consumption } \\
\hline 2.19 & 2.62 & 3.5 & 5.25 & 7.0 & 10.5 & \\
\hline 1.71 & 1.63 & 2.18 & 3.29 & 4.30 & 7.74 & \\
\hline 1.39 & 1.13 & 0.90 & 2.01 & 3.19 & 7.10 & \\
\hline 1.14 & 0.93 & 0.70 & 1.17 & 2.65 & 6.62 & \\
\hline 1.08 & 0.81 & 0.31 & 0.91 & 2.41 & 6.34 & \\
\hline 1.07 & 0.80 & 0.19 & 0.84 & 2.30 & 6.28 & \\
\hline 1.03 & 0.78 & 0.06 & 0.80 & 2.25 & 6.13 & \\
\hline \multicolumn{7}{|c|}{ Matrix of sulfide production } \\
\hline 0 & 0.09 & 0.29 & 0.48 & 0.53 & 0.54 & 0.57 \\
\hline 0.12 & 0.59 & 0.96 & 1.72 & 2.49 & 2.60 & 0.73 \\
\hline 0.23 & 0.83 & 1.93 & 2.78 & 3.68 & 3.32 & 1.58 \\
\hline 0.29 & 1.21 & 2.29 & 3.54 & 4.21 & 3.75 & 1.50 \\
\hline 0.31 & 1.40 & 2.38 & 3.83 & 4.37 & 3.95 & 1.51 \\
\hline 0.33 & 1.38 & 2.48 & 3.94 & 4.48 & 4.01 & 1.53 \\
\hline 0.33 & 0.71 & 1.58 & 2.53 & 3.03 & 2.63 & 0 \\
\hline \multicolumn{7}{|c|}{ Matrix of lactate consumption } \\
\hline 10.87 & 13.10 & 17.3 & 26.45 & 35.35 & 53.15 & \\
\hline 9.34 & 10.66 & 13.68 & 17.71 & 26.56 & 43.92 & \\
\hline 7.68 & 7.42 & 8.50 & 12.59 & 20.23 & 38.75 & \\
\hline 6.82 & 6.17 & 5.10 & 9.28 & 17.88 & 36.73 & \\
\hline 6.36 & 4.62 & 4.20 & 8.84 & 17.04 & 35.94 & \\
\hline 5.76 & 4.27 & 2.15 & 8.89 & 16.29 & 35.39 & \\
\hline 5.55 & 3.91 & 0.67 & 8.79 & 15.74 & 34.94 & \\
\hline \multicolumn{7}{|c|}{ Matrix of acetate production } \\
\hline 0 & 0.46 & 1.18 & 1.61 & 1.69 & 1.72 & 1.74 \\
\hline 0.54 & 1.66 & 4.07 & 5.52 & 6.43 & 7.06 & 3.88 \\
\hline 1.04 & 3.22 & 7.80 & 9.39 & 10.83 & 13.0 & 7.81 \\
\hline 1.47 & 6.5 & 12.20 & 14.55 & 15.52 & 16.05 & 8.60 \\
\hline 1.84 & 6.75 & 13.25 & 16.41 & 17.21 & 17.97 & 10.55 \\
\hline 2.41 & 6.28 & 12.92 & 15.51 & 16.21 & 16.71 & 9.15 \\
\hline 2.60 & 4.11 & 7.81 & 8.05 & 8.05 & 8.05 & 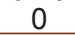 \\
\hline
\end{tabular}

The sizes of obtained matrices were $7 \times 7$ for biomass, sulfide and acetate production and $6 \times 7$ for sulfate and lactate consumption.

Based on these matrices were constructed surface models of sulfate reduction parameters by $D$. piger Vib-7 under influence of electron donor and acceptor different concentrations (Fig. 3). The obtained surface models show that bacteria D. piger Vib-7 intensively grown in the media containing increased concentrations of electron acceptor and donor (sulfate and lactate, respectively). The most intense sulfate reduction process occurs at concentrations within $3.5-10.5 \mathrm{mM}$ of sulfate and $17.8-89.0 \mathrm{mM}$ of lactate. The optimum concentration for the production of hydrogen sulfide were $10.5 \mathrm{mM}$ of sulfate and $53.4 \mathrm{mM}$ of lactate. The bacteria $D$. piger Vib-7 most intensively used lactate in media which contained $7.0 \mathrm{mM}$ of sulfate and $17.8-35.6 \mathrm{mM}$ of lactate. Acetate production most intensively occurred at increased concentrations $(10.5 \mathrm{mM}$ of sulfate and $53.4 \mathrm{mM}$ of lactate). 


\section{Bacterial growth}

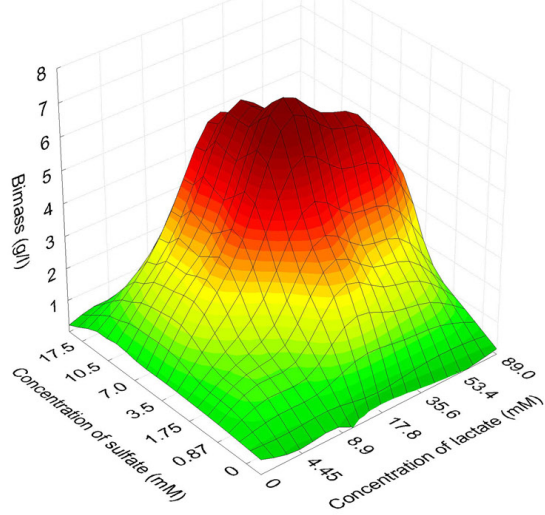

Production of sulfide

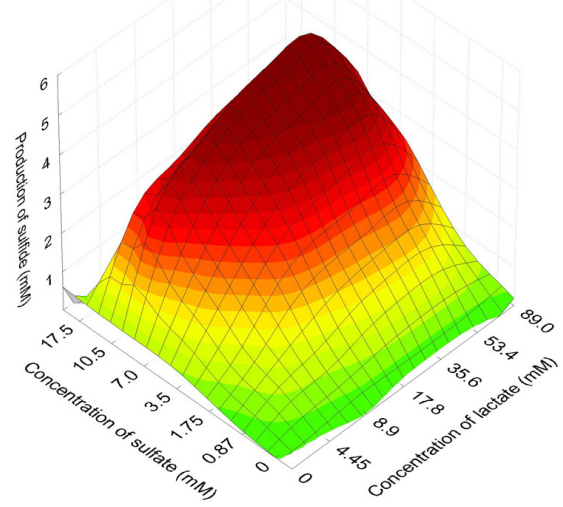

Production of acetate

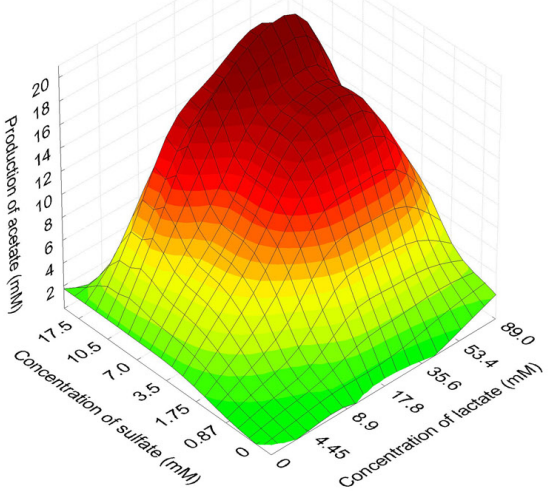

Sulfate utilization

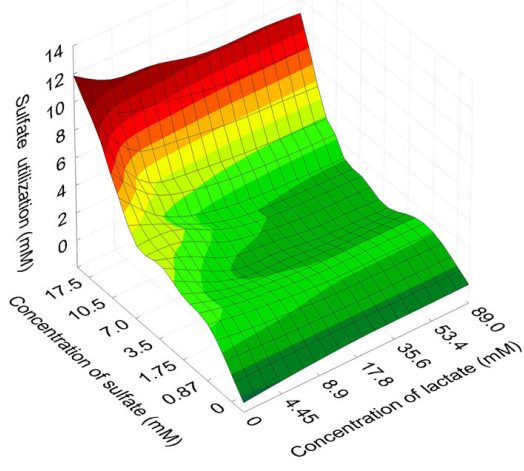

Lactate utilization

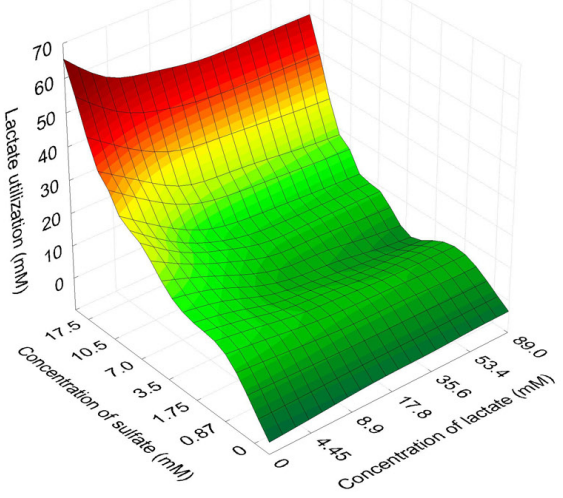

Fig. 3. Surface models of parameters of sulfate reduction by Desulfovibrio piger Vib-7 bacteria under the influence of electron acceptor and donor used in different concentrations (3D surface)

Рис. 3. Моделі поверхонь параметрів сульфатредукції, здійснюваної бактеріями Desulfovibrio piger Vib-7 за впливу різних концентрацій акцептора і донора електронів (3D поверхня) 
Thus, the constructed surface models have provided an opportunity to confirm and establish the optimum growing point by the studied bacteria, their sulfate consumption and sulfide production, and the lactate consumption and acetate accumulation.

Obviously, the increased concentration of electron acceptor and donor can cause intense growth of the studied bacteria $D$. piger Vib-7 as well as intensive accumulation of sulfide and acetate in the human intestine. These conditions may be the cause of ulcerative colitis and in turn bowel cancer. Hydrogen sulfide has negatively affects on the intestinal mucosa, it is toxic to epithelial cells, specifically inhibits the growth of the colonocytes $[2,11]$, phagocytosis, causes the death of intestinal bacteria $[5,6,14]$, induces hyperproliferation and metabolic abnormalities of epithelial cells [2]. It was found that the high level of this metabolite and the presence of SRB significantly increased during inflammation of the colon $[5,13,15]$. Therefore, regulation of the concentration of hydrogen sulfide in the colon is very important to maintain the integrity of the colonocytes [2, 11].

A correlation analysis is related in the sense that both deal with relationships among variables. The correlation coefficient is a measure of linear association between two variables [4]. Therefore, the next task of the study was perform the correlation analysis between parameters of dissimilatory sulfate reduction.

The correlation coefficients $(r)$ between the parameters by the $D$. piger Vib-7 were defined (Table 2). Between biomass and sulfate; biomass and lactate; sulfate and sulfide; sulfate and acetate; lactate and acetate; as well as lactate and sulfide a strong inversely negative correlation has been demonstrated. Between biomass and sulfide; biomass and acetate; lactate and sulfate; acetate and sulfide a strong positive correlation has been demonstrated.

The correlation coefficient ranges from -1.0 to +1.0 . The closer $r$ is to +1 or -1 , the more closely the two variables are related. If $r$ is close to 0 , it means there is no relationship between the variables. If $r$ is positive, it means that as one variable gets larger the other gets larger. If $r$ is negative it means that as one gets larger, the other gets smaller (often called an "inverse" correlation). While correlation coefficients are normally reported as $r=($ a value between -1 and +1$)$, squaring them makes then easier to understand. Values between 0.7 and $1.0(-0.7$ and -1.0$)$ indicate a strong positive (negative) linear relationship via a firm linear rule [4].

\section{CONCLUSIONS}

Increasing the concentrations of sulfate and lactate up to $17.4 \mathrm{mM}$ and $35.6 \mathrm{mM}$ respectively in the culture medium leads to actively growth and producing hydrogen sulfide by the studied $D$. piger Vib-7. The largest quantity of hydrogen sulfide $(6.06 \mathrm{mM})$ under influence of $10.5 \mathrm{mM}$ of $\mathrm{SO}_{4}^{2-}$ was detected on the 72 hour of cultivation; while the bacteria $D$. piger Vib-7 used about $58 \%$ of sulfate ion. The largest quantity of acetate $(21.10 \mathrm{mM}$ ) was detected on the 72 hour of cultivation during cultivating the $D$. piger Vib-7 in the medium which contained $53.4 \mathrm{mM}$ of lactate.

Based on obtained results matrices of surface models of sulfate reduction parameters by $D$. piger Vib-7 under influence of electron donor and acceptor used in different concentrations were constructed. These surface models have provided an opportunity to confirm and establish the optimum growing point by the studied bacteria, their sulfate consumption and sulfide production, and the lactate consumption and acetate accumulation.

The correlation coefficients $(r)$ between the parameters of dissimilatory sulfate reduction by the $D$. piger Vib-7 were defined. Strong negative and positive correlations between the parameters have been demonstrated.

ISSN 1996-4536 (print) • ISSN 2311-0783 (on-line) • Біологічні Студії / Studia Biologica • 2014 • Том 8/№1 • С. 103-116 
Table 2. Coefficients of correlation $(r)$ between parameters of dissimilatory sulfate reduction carried out by the Desulfovibrio piger Vib-7 bacteria

Таблиця 2. Коефіцієнти кореляції (r) між параметрами дисиміляційного відновлення сульфату, здійснюваного бактеріями Desulfovibrio piger Vib-7

\begin{tabular}{|c|c|c|c|c|c|c|c|c|c|c|c|}
\hline & & & $.87 \mathrm{mM} \mathrm{c}$ & f sulfate & & & & 4.45 & $\mathrm{mM}$ of lac & ctate & \\
\hline & & Biomass & Sulfate & Sulfide & Lactate & Acetate & Biomass & Sulfate & Sulfide & Lactate & Acetate \\
\hline$\stackrel{0}{\frac{0}{0}}$ & Biomass & 1 & -0.952 & 0.991 & -0.981 & 0.964 & 0.994 & -0.995 & 0.988 & -0.981 & 0.986 \\
\hline 告 & Sulfate & -0.952 & 1 & -0.982 & 0.9 & -0.857 & -0.972 & 0.968 & -0.921 & 0.991 & -0.98 \\
\hline$\sum^{4}$ & Sulfide & 0.991 & -0.982 & 1 & -0.963 & 0.935 & 0.995 & -0.996 & 0.976 & -0.997 & 0.998 \\
\hline$\underline{E}$ & Lactate & -0.981 & 0.9 & -0.963 & 1 & -0.996 & -0.973 & 0.968 & -0.975 & 0.941 & -0.953 \\
\hline$\infty$ & Acetate & 0.964 & -0.857 & 0.935 & -0.996 & 1 & 0.95 & -0.946 & 0.965 & -0.908 & 0.925 \\
\hline$\stackrel{0}{\pi}$ & Biomass & 0.994 & -0.972 & 0.995 & -0.973 & 0.95 & 1 & -0.992 & 0.97 & -0.987 & 0.986 \\
\hline U & Sulfate & -0.995 & 0.968 & -0.996 & 0.968 & -0.946 & -0.992 & 1 & -0.988 & 0.991 & -0.995 \\
\hline$\underbrace{4}$ & Sulfide & 0.988 & -0.921 & 0.976 & -0.975 & 0.965 & 0.97 & -0.988 & 1 & -0.965 & 0.979 \\
\hline हू & Lactate & -0.981 & 0.991 & -0.997 & 0.941 & -0.908 & -0.987 & 0.991 & -0.965 & 1 & -0.998 \\
\hline$\stackrel{\text { i }}{\dot{A}}$ & Acetate & 0.986 & -0.98 & 0.998 & -0.953 & 0.925 & 0.986 & -0.995 & 0.979 & -0.998 & 1 \\
\hline & & & $.75 \mathrm{mM} \mathrm{c}$ & of sulfate & & & & $8.9 n$ & $\mathrm{M}$ of lact & tate & \\
\hline & & Biomass & Sulfate & Sulfide & Lactate & Acetate & Biomass & Sulfate & Sulfide & Lactate & Acetate \\
\hline$\frac{0}{0}$ & Biomass & 1 & -0.99 & 0.99 & -0.96 & 0.911 & 0.998 & -0.964 & 0.969 & -0.983 & 0.983 \\
\hline क & Sulfate & -0.99 & 1 & -0.995 & 0.939 & -0.864 & -0.995 & 0.987 & -0.989 & 0.994 & -0.994 \\
\hline$\sum^{0}$ & Sulfide & 0.99 & -0.995 & 1 & -0.967 & 0.899 & 0.99 & -0.97 & 0.986 & -0.997 & 0.997 \\
\hline $\bar{E}$ & Lactate & -0.96 & 0.939 & -0.967 & 1 & -0.968 & -0.948 & 0.885 & -0.926 & 0.957 & -0.957 \\
\hline$\stackrel{\infty}{\infty}$ & Acetate & 0.911 & -0.864 & 0.899 & -0.968 & 1 & 0.887 & -0.778 & 0.821 & -0.872 & 0.872 \\
\hline$\stackrel{\oplus}{\mathbb{2}}$ & Biomass & 0.998 & -0.995 & 0.99 & -0.948 & 0.887 & 1 & -0.977 & 0.979 & -0.987 & 0.987 \\
\hline U & Sulfate & -0.964 & 0.987 & -0.97 & 0.885 & -0.778 & -0.977 & 1 & -0.991 & 0.98 & -0.98 \\
\hline$\sum^{4}$ & Sulfide & 0.969 & -0.989 & 0.986 & -0.926 & 0.821 & 0.979 & -0.991 & 1 & -0.995 & 0.995 \\
\hline हू & Lactate & -0.983 & 0.994 & -0.997 & 0.957 & -0.872 & -0.987 & 0.98 & -0.995 & 1 & -1 \\
\hline$\stackrel{\dot{v}}{\dot{\gamma}}$ & Acetate & 0.983 & -0.994 & 0.997 & -0.957 & 0.872 & 0.987 & -0.98 & 0.995 & -1 & 1 \\
\hline & & & $3.5 \mathrm{mM} \mathrm{o}$ & sulfate & & & & 17.8 & $\mathrm{mM}$ of lac & ctate & \\
\hline & & Biomass & Sulfate & Sulfide & Lactate & Acetate & Biomass & Sulfate & Sulfide & Lactate & Acetate \\
\hline$\frac{0}{0}$ & Biomass & 1 & -0.987 & 0.992 & -0.994 & 0.994 & 1 & -0.987 & 0.992 & -0.994 & 0.994 \\
\hline$\frac{\pi}{5}$ & Sulfate & -0.987 & 1 & -0.982 & 0.973 & 0.973 & -0.987 & 1 & -0.982 & 0.973 & -0.973 \\
\hline 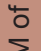 & Sulfide & 0.992 & -0.982 & 1 & -0.992 & 0.992 & 0.992 & -0.982 & 1 & -0.992 & 0.992 \\
\hline E & Lactate & -0.994 & 0.973 & -0.992 & 1 & -1 & -0.994 & 0.973 & -0.992 & 1 & -1 \\
\hline 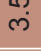 & Acetate & 0.994 & -0.973 & 0.992 & -1 & 1 & 0.994 & -0.973 & 0.992 & -1 & 1 \\
\hline$\stackrel{0}{\mathbb{T}}$ & Biomass & 1 & -0.987 & 0.992 & -0.994 & 0.994 & 1 & -0.987 & 0.992 & -0.994 & 0.994 \\
\hline 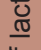 & Sulfate & -0.987 & 1 & -0.982 & 0.973 & -0.973 & -0.987 & 1 & -0.982 & 0.973 & -0.973 \\
\hline$\sum^{4}$ & Sulfide & 0.992 & -0.982 & 1 & -0.992 & 0.992 & 0.992 & -0.982 & 1 & -0.992 & 0.992 \\
\hline $\bar{E}$ & Lactate & -0.994 & 0.973 & -0.992 & 1 & -1 & -0.994 & 0.973 & -0.992 & 1 & -1 \\
\hline 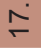 & Acetate & 0.994 & -0.973 & 0.992 & -1 & 1 & 0.994 & -0.973 & 0.992 & -1 & 1 \\
\hline
\end{tabular}

ISSN 1996-4536 (print) • ISSN 2311-0783 (on-line) • Біологічні Студії / Studia Biologica • 2014 • Том 8/№1 • C. $103-116$ 
Continued Table 2

Закінчення табл. 2

\begin{tabular}{|c|c|c|c|c|c|c|c|c|c|c|c|}
\hline & \multicolumn{6}{|c|}{$7 \mathrm{mM}$ of sulfate } & \multicolumn{5}{|c|}{$35.6 \mathrm{mM}$ of lactate } \\
\hline & & Biomass & Sulfate & Sulfide & Lactate & Acetate & Biomass & Sulfate & Sulfide & Lactate & Acetate \\
\hline \multirow{5}{*}{ 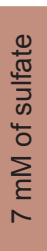 } & Biomass & 1 & -0.997 & 0.995 & -0.99 & 0.99 & 0.987 & -0.991 & 0.998 & -0.991 & 0.993 \\
\hline & Sulfate & -0.997 & 1 & -0.999 & 0.992 & -0.992 & -0.991 & 0.991 & -0.995 & 0.993 & -0.995 \\
\hline & Sulfide & 0.995 & -0.999 & 1 & -0.988 & 0.988 & 0.987 & -0.987 & 0.992 & -0.989 & 0.991 \\
\hline & Lactate & -0.99 & 0.992 & -0.988 & 1 & -1 & -0.999 & 0.999 & -0.995 & 1 & -1 \\
\hline & Acetate & 0.99 & -0.992 & 0.988 & -1 & 1 & 0.999 & -0.999 & 0.995 & -1 & 1 \\
\hline \multirow{7}{*}{ 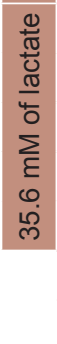 } & Biomass & 0.987 & -0.991 & 0.987 & -0.999 & 0.999 & 1 & -0.999 & 0.994 & -0.999 & 0.999 \\
\hline & Sulfate & -0.991 & 0.991 & -0.987 & 0.999 & -0.999 & -0.999 & 1 & -0.997 & 0.999 & -0.999 \\
\hline & Sulfide & 0.998 & -0.995 & 0.992 & -0.995 & 0.995 & 0.994 & -0.997 & 1 & -0.996 & 0.997 \\
\hline & Lactate & -0.991 & 0.993 & -0.989 & 1 & -1 & -0.999 & 0.999 & -0.996 & 1 & -1 \\
\hline & Acetate & 0.993 & -0.995 & 0.991 & -1 & 1 & 0.999 & -0.999 & 0.997 & -1 & 1 \\
\hline & \multicolumn{6}{|c|}{$10.5 \mathrm{mM}$ of sulfate } & \multicolumn{5}{|c|}{$53.4 \mathrm{mM}$ of lactate } \\
\hline & & Biomass & Sulfate & Sulfide & Lactate & Acetate & Biomass & Sulfate & Sulfide & Lactate & Acetate \\
\hline \multirow{5}{*}{ 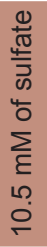 } & Biomass & 1 & -0.986 & 0.986 & -0.979 & 0.979 & 0.998 & -0.994 & 0.999 & -0.992 & 0.992 \\
\hline & Sulfate & -0.986 & 1 & -1 & 0.998 & -0.998 & -0.993 & 0.997 & -0.991 & 0.968 & -0.968 \\
\hline & Sulfide & 0.986 & -1 & 1 & -0.998 & 0.998 & 0.993 & -0.997 & 0.991 & -0.968 & 0.968 \\
\hline & Lactate & -0.979 & 0.998 & -0.998 & 1 & -1 & -0.989 & 0.994 & -0.986 & 0.957 & -0.957 \\
\hline & Acetate & 0.979 & -0.998 & 0.998 & -1 & 1 & 0.989 & -0.994 & 0.986 & -0.957 & 0.957 \\
\hline \multirow{7}{*}{ 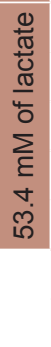 } & Biomass & 0.998 & -0.993 & 0.993 & -0.989 & 0.989 & 1 & -0.998 & 0.999 & -0.984 & 0.984 \\
\hline & Sulfate & -0.994 & 0.997 & -0.997 & 0.994 & -0.994 & -0.998 & 1 & -0.998 & 0.98 & -0.98 \\
\hline & Sulfide & 0.999 & -0.991 & 0.991 & -0.986 & 0.986 & 0.999 & -0.998 & 1 & -0.99 & 0.99 \\
\hline & Lactate & -0.992 & 0.968 & -0.968 & 0.957 & -0.957 & -0.984 & 0.98 & -0.99 & 1 & -1 \\
\hline & Acetate & 0.992 & -0.968 & 0.968 & -0.957 & 0.957 & 0.984 & -0.98 & 0.99 & -1 & 1 \\
\hline & \multicolumn{6}{|c|}{$17.5 \mathrm{mM}$ of sulfate } & \multicolumn{5}{|c|}{$89 \mathrm{mM}$ of lactate } \\
\hline & & Biomass & Sulfate & Sulfide & Lactate & Acetate & Biomass & Sulfate & Sulfide & Lactate & Acetate \\
\hline \multirow{5}{*}{ 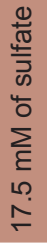 } & Biomass & 1 & -0.921 & 0.921 & -0.922 & 0.922 & 0.994 & -0.988 & 0.995 & -0.995 & 0.995 \\
\hline & Sulfate & -0.921 & 1 & -1 & 0.986 & -0.986 & -0.944 & 0.967 & -0.952 & 0.912 & -0.912 \\
\hline & Sulfide & 0.921 & -1 & 1 & -0.986 & 0.986 & 0.944 & -0.967 & 0.952 & -0.912 & 0.912 \\
\hline & Lactate & -0.922 & 0.986 & -0.986 & 1 & -1 & -0.937 & 0.968 & -0.951 & 0.897 & -0.897 \\
\hline & Acetate & 0.922 & -0.986 & 0.986 & -1 & 1 & 0.937 & -0.968 & 0.951 & -0.897 & 0.897 \\
\hline \multirow{5}{*}{ 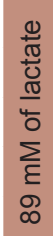 } & Biomass & 0.994 & -0.944 & 0.944 & -0.937 & 0.937 & 1 & -0.994 & 0.998 & -0.991 & 0.992 \\
\hline & Sulfate & -0.988 & 0.967 & -0.967 & 0.968 & -0.968 & -0.994 & 1 & -0.998 & 0.978 & -0.978 \\
\hline & Sulfide & 0.995 & -0.952 & 0.952 & -0.951 & 0.951 & 0.998 & -0.998 & 1 & -0.988 & 0.988 \\
\hline & Lactate & -0.995 & 0.912 & -0.912 & 0.897 & -0.897 & -0.991 & 0.978 & -0.988 & 1 & -1 \\
\hline & Acetate & 0.995 & -0.912 & 0.912 & -0.897 & 0.897 & 0.992 & -0.978 & 0.988 & -1 & 1 \\
\hline
\end{tabular}

ISSN 1996-4536 (print) • ISSN 2311-0783 (on-line) • Біологічні Студії / Studia Biologica • 2014 • Том 8/№1 • C. 103-116 


\section{ACKNOWLEDGEMENTS}

The author expresses his gratitude to Lucy Mclennan and Robyn Cochrane from the Forensic Biology at University of Strathclyde (Scotland, United Kingdom) for their assistance and reading of the manuscript.

1. Bailey N.T.J. Statistical Methods in Biology. Cambridge University Press. $3^{\text {rd }}$ edition 1995; $252 \mathrm{p}$.

2. Barton L.L., Hamilton W.A. Sulphate-reducing Bacteria. Environmental and Engineered. Cambridge University Press, 2007; 553 p.

3. Campbell M.K., Farrell S.O. Biochemistry. Sixth Edition. Publisher: Cengage Learning. 2008; $800 \mathrm{p}$

4. Chen P.Y., Popovich P.M. Correlation: Parametric and Nonparametric Measures. Sage University Papers Series on Quantitative Applications in the Social Sciences. 2002; 104 p.

5. Cummings J.H., Macfarlane G.T., Macfarlane S. Intestinal Bacteria and Ulcerative Colitis. Curr. Issues Intest. Microbiol, 2003; 4: 9-20.

6. Gibson G.R., Cummings J.H., Macfarlane G.T. Growth and activities of sulphate-reducing bacteria in gut contents of health subjects and patients with ulcerative colitis. FEMS Microbiol. Ecol, 1991; 86: 103-112.

7. Gibson G.R., Macfarlane S., Macfarlane G.T. Metabolic interactions involving sulphate-reducing and methanogenic bacteria in the human large intestine. FEMS Microbiol. Ecol, 1993; 12: 117-125.

8. Isakova O.P., Tarasevych Yu.Yu., Yuzjuk Yu.I. Processing and visualization of data with the physical experiments by usage Origin package. Moscow Book House "LIBKOM", 2009; $136 \mathrm{p}$.

9. Kolmert A., Wikstrom P., Hallberg K.B. A fast and simple turbidimetric method for the determination of sulfate in sulfate-reducing bacterial cultures. Journal of Microbiol. Methods, 2000; 41: 179-184.

10. Kushkevych I.V. Sulfate-reducing bacteria of the human intestine. I. Dissimilatory sulfate reduction. Sci. Int. Journ. Biological studies/Studia Biologica, 2012; 6(1), 149-180.

11. Kushkevych I.V. Sulfate-reducing bacteria of the human intestine. II. The role in the diseases development. Sci. Int. Journ. Biological studies/Studia Biologica, 2012; 6(2): 221-250.

12. Kushkevych I.V. Identification of sulfate-reducing bacteria strains of the human large intestine. Sci. Int. Journ. Biological studies/Studia Biologica, 2013; 7(3): 115-132.

13. Loubinoux J., Bronowicji J.P., Pereira I.A. et al. Sulphate-reducing bacteria in human feces and their association with inflammatory diseases. FEMS Microbiol. Ecol, 2002; 40: 107-112.

14. Loubinoux J., Mory F., Pereira I.A., Le Faou A.E. Bacteremia caused by a strain of Desulfovibrio related to the provisionally named Desulfovibrio fairfieldensis. Journal Clin. Microbiol, 2000; 38: 931-934.

15. Pitcher M.C., Cummings J.H. Hydrogen sulphide: a bacterial toxin in ulcerative colitis? Gut, 1996; 39: 1-4.

16. Sutton S. Measurement of Microbial Cells by Optical Density. Journal of Validation Technology, 2011; 17(1): 46-49.

17. Vlizlo V.V., Fedoruk R.S., Makar I.A. et al. Physiological and biochemical methods of researches in biology, stockbreeding and veterinary medicine. Handbook Institute of Animal Biology. Third Edition: revised and enlarged Lviv. 2004; 402 p. 


\section{ВПЛИВ КОНЦЕНТРАЦІЇ АКЦЕПТОРА І ДОНОРА ЕЛЕКТРОНІВ НА ДИСИМІЛЯЦІЙНЕ ВІДНОВЛЕННЯ СУЛЬФАТІВ БАКТЕРІЯМИ DESULFOVIBRIO PIGER VIB-7 КИШЕЧНИКА ЛЮДИНИ}

\section{І. В. Кушкевич}

Університет ветеринарних і фармацевтичних наук Брно Palackeho, 1/3, CZ-61242 Брно, Чеська Республіка e-mail: ivan.kushkevych@gmail.com

Досліджено ріст бактерій Desulfovibrio piger Vib-7 кишечника людини за різних концентрацій акцептора і донора електронів, а також параметри дисиміляційного відновлення сульфату. Збільшення інтенсивності бактеріального росту і продукування гідроген сульфіду досліджуваними $D$. piger Vib-7 спостерігали за впливу високих концентрацій сульфату і лактату (17,4 та 35,6 мМ, відповідно) у середовищі культивування. Найбільша кількість гідроген сульфіду (6,06 мМ) виявлена за впливу 10,5 мM SO ${ }_{4}^{2-}$ на 72 год культивування; за цих умов бактерії D. piger Vib-7 використали приблизно 58 \% сульфат іонів. Найбільша концентрація ацетату (21,1 мМ) виявлена на 72 год культивування під час росту D. piger Vib-7 у середовищі, яке містило 53,4 мМ лактату. На основі експериментальних даних побудовано моделі поверхонь параметрів сульфратредукції, здійснюваної бактеріями D. piger Vib-7 за впливу різних концентрацій акцептора і донора електронів. Ці моделі поверхонь дали змогу підтвердити і встановити оптимальні точки росту досліджуваних бактерій, їхні параметри використання сульфату й утворення гідроген сульфіду, а також використання лактату і нагромадження ацетату. Визначено кореляційні коефріцієнти (r) між параметрами дисиміляційного відновлення сульфату бактеріями D. piger Vib-7. Встановлено сильну негативну і позитивну кореляції між цими параметрами.

Ключові слова: сульфатвідновлювальні бактерії, Desulfovibrio piger, сульфати, гідроген сульфід, запальні захворювання кишечника, неспецифрічний виразковий коліт.

\section{ВЛИЯНИЕ КОНЦЕНТРАЦИИ АКЦЕПТОРА И ДОНОРА ЭЛЕКТРОНОВ НА ДИССИМИЛЯЦИОННОЕ ВОССТАНОВЛЕНИЕ СУЛЬФАТОВ БАКТЕРИЯМИ DESULFOVIBRIO PIGER VIB-7 КИШЕЧНИКА ЧЕЛОВЕКА}

И. В. Кушкевич

Университет ветеринарных и фармацевтических наук Брно Palackeho, 1/3, CZ-61242 Брно, Чешская Республика e-mail: ivan.kushkevych@gmail.com

Исследованы рост бактерий Desulfovibrio piger штамм Vib-7 кишечника человека при различных концентрациях акцептора и донора электронов, а также параметры диссимиляционного восстановления сульфата. Увеличение интенсивности бактериального роста и продуцирования гидроген сульфида исследуемыми D. piger Vib-7 наблюдали при воздействии высоких концентраций сульфата и лактата $(17,4$ и 35,6 мМ, соответственно) в среде культивирования. Наибольшее количество гидроген сульфида (6,06 мМ) обнаружено при воздействии 10,5 мM SO $42-$

ISSN 1996-4536 (print) • ISSN 2311-0783 (on-line) • Біологічні Студії / Studia Biologica • 2014 • Том 8/№1 • C. 103-116 
на 72 час культивирования; в этих условиях бактерии D. piger Vib-7 использовали примерно 58 \% сульфат ионов. Наибольшая концентрация ацетата (21,1 мМ) обнаружена на 72 час культивирования во время роста D. piger Vib-7 в среде, содержащей 53,4 мМ лактата. На основе экспериментальных данных построены модели поверхностей параметров сульфатредукции, осуществляемой бактериями D. piger Vib-7, при воздействии различных концентраций акцептора и донора электронов. Эти модели поверхностей позволили подтвердить и установить оптимальные точки роста исследуемых бактерий, их параметры использования сульфата и образование гидроген сульфида, а также использование лактата и накопления ацетата. Определены корреляционные коэффицциенты (r) между параметрами диссимиляционного восстановления сульфата бактериями D. piger Vib-7. Установлены сильные негативная и позитивная корреляции между этими параметрами.

Ключевые слова: сульфат-восстановительные бактерии, Desulfovibrio piger, сульфаты, гидроген сульфид, воспалительные заболевания кишечника, неспецифический язвенный колит.

Одержано: 03.08.2013

ISSN 1996-4536 (print) • ISSN 2311-0783 (on-line) • Біологічні Студії / Studia Biologica • 2014 • Том 8/№1 • C. $103-116$ 